\title{
Survey of protozoan, helminth and viral infections in shrimp Litopenaeus setiferus and prawn Macrobrachium acanthurus native to the Jamapa River region, Mexico
}

\author{
Magda E. Domínguez-Machín ${ }^{1,2}$, Martha P. Hernández-Vergara1, \\ Isabel Jiménez-García ${ }^{1}$, Raúl Simá-Álvarez ${ }^{3}$, Rossanna Rodríguez-Canul ${ }^{3, *}$ \\ ${ }^{1}$ Instituto Tecnológico de Boca del Río, Carr. Veracruz-Córdoba Km. 12, 94290 Boca del Río, Veracruz, Mexico \\ ${ }^{2}$ Instituto Nacional de Pesca, Dirección General de Investigación en Acuacultura, Pitágoras 1320, \\ 3er. Piso. Col. Sta. Cruz Atoyac, 03310 México DF, Mexico \\ ${ }^{3}$ Laboratorio de Inmunología y Biología Molecular, Centro de Investigación y de Estudios Avanzados del Instituto \\ Politécnico Nacional-Unidad Mérida, Antigua Carretera a Progreso Km. 6, 97310 Mérida, Yucatán, Mexico
}

\begin{abstract}
We surveyed protozoan and metazoan parasites as well as white spot syndrome virus (WSSV) and infectious hypodermal hematopoietic necrosis virus (IHHNV) in white shrimp Litopenaeus setiferus and the palaemonid prawn Macrobrachium acanthurus native to the lower Jamapa River region of Veracruz, Mexico. The presence of parasites and the infection parameters were evaluated in 113 palaemonid prawns collected during the northwind $(n=45)$, rainy $(n=38)$ and dry seasons $(n=30)$ between October 2007 and July 2008, and in 91 shrimp collected in the rainy season between May and June 2008. In L. setiferus, ciliates of the subclass Apostomatia (Ascophrys sp.) were evident in gills, and third-stage larvae of the nematode Physocephalus sexalatus were evident in the stomach. Cestodes of the genus Prochristianella were evident in the hepatopancreas, while some gregarines of the genus Nematopsis, as well as unidentified larval cestodes, were observed in the intestine. Histology identified Ascophrys sp. in association with gill necrosis and tissue melanization. Slight inflammation was observed in intestinal epithelium near cestode larvae. In M. acanthurus, epibionts of the protozoans Epistylis sp., Acineta sp. and Lagenophrys sp. were observed under uropods, periopods and pleopods. An unidentified ciliate of the Apostomatia was also found in the gills, and Nematopsis was identified in the intestine. No histopathology was observed in association with these parasites. Moreover, neither WSSV nor IHHNV were detected by the polymerase chain reaction (PCR) in any of the L. setiferus or $M$. acanthurus analysed.
\end{abstract}

KEY WORDS: Litopenaeus setiferus · Macrobrachium acanthurus - WSSV · IHHNV · Helminths · Mexico

Resale or republication not permitted without written consent of the publisher

\section{INTRODUCTION}

Crustacean fisheries in the Gulf of Mexico generate the third largest total catch volume, behind tilapia and oysters, with annual catches in Mexico ranging between 22000 and $24000 \mathrm{t}$ and representing about a third of total fishery production (Schultz et al. 2002).
The shrimp fisheries of the Gulf of Mexico and the Caribbean Sea catch mainly the following species: Farfantepenaeus aztecus, F. brasilensis, F. duorarum and Litopenaeus setiferus (Gracia \& HernándezAguilera 2005). Other crustaceans, including crabs (species of Callinectes, Cardisoma, Ucides and Menippe), crayfish (family: Astacidae), and palaemonid 
prawns (Macrobrachium acanthurus, M. carcinus and $M$. heterochirus) are also fished commercially, with palaemonid prawns being more valuable than shrimp, even though catch volumes are significantly lower (Lorán-Nuñez \& Martínez-Isunza 2002).

The health status of cultured and wild shrimp has been reported from some areas of Mexico (ChávezSánchez et al. 2002, Vidal Martínez et al. 2002, López-Téllez et al. 2009), but little is known about the health status of palaemonid prawns. For instance, white spot syndrome virus (WSSV) and infectious hypodermal and hematopoietic necrosis virus (IHHNV) have caused serious outbreaks of disease in shrimp farmed in the Americas (Lightner 1996 p. 304, Aguirre-Guzmán \& Ascencio-Valle 2000), but whether infections exist in Macrobrachium acanthurus native to Mexico has not been determined.

We report the results of a survey to determine the presence of WSSV and IHHNV, as well as epibionts and parasites, in shrimp Litopenaeus setiferus and palaemonid prawn Macrobrachium acanthurus native to the lower Jamapa River region of Veracruz, Mexico.

\section{MATERIALS AND METHODS}

Samples. Sampling sites for shrimp Litopenaeus setiferus and palaemonid prawn Macrobrachium acanthurus were located in an area 1 to $5 \mathrm{~km}$ upstream of the mouth of the Jamapa River in Veracruz

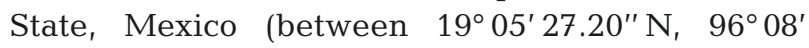
$25.30^{\prime \prime} \mathrm{W}$ and $\left.19^{\circ} 06^{\prime} 16.23^{\prime \prime} \mathrm{N}, 96^{\circ} 06^{\prime} 46.94^{\prime \prime} \mathrm{W}\right)$. This part of the river is subject to wastewater discharge from nearby houses and aquaculture farms. Palaemonid prawns $(n=113)$ were collected between October 2007 and July 2008 in the northwind season (November to February) ( $\mathrm{n}=45)$, the dry season (March to June) ( $\mathrm{n}=38$ ) and the rainy season (July to October) (n = 30). Prawns were trapped in cylindrical, metalmesh traps $(20 \mathrm{~cm}$ diameter $\times 40 \mathrm{~cm}$ in height) containing raw fish bait $(10 \mathrm{~cm} \times 10 \mathrm{~cm})$. Two traps were placed at each of 5 sampling sites about $3 \mathrm{~m}$ from shore (total $=10$ traps) and left for $12 \mathrm{~h}$. Based on epidemiological tables for a given population size of $\geq 10000$, a minimum sample size of 60 individuals per season was chosen to detect a prevalence of infection down to $10 \%$ at a confidence level $\geq 95 \%$ (Lightner 1996 p. 304). Using a 1 inch mesh cast net, shrimp ( $\mathrm{n}=$ 91) were caught at night during the rainy season while making their seasonal migration from wetlands to the sea. All crustaceans were transported alive to the Instituto Tecnológico de Boca del Río, Veracruz, in plastic containers filled with water from the river, aerated continually, until they were sampled.

Parasitology. A total of 30 shrimp and 90 palaemonid prawns (30 per season) were examined for parasites. Total length (TL, cm) from the tip of the rostrum to the distal telson, total weight $(\mathrm{g})$ and gender, based on the presence of reproductive or telic appendages, were recorded. Epibionts and parasites were identified and quantified by light microscopy using $10 \times, 40 \times$ and $100 \times$ objectives. All shrimp and prawns were dissected, and the cuticle, appendages, gills, muscle, digestive tract, hepatopancreas and intestine were examined. Parasites were identified based on descriptions of species morphology (Couch 1983, Moravec et al. 1995, Lightner 1996 p. 304, Vidal-Martínez et al. 2002, Fernández-Leborans et al. 2006).

Histology. Groups of 15 shrimp caught in the rainy season, and 45 palaemonid prawns (15 per season), were fixed for $48 \mathrm{~h}$ in Davidson's solution and processed for embedding in paraffin wax; $5 \mu \mathrm{m}$ tissue sections were stained with hematoxylin and eosin (H\&E). Light microscopy was used to identify and to describe pathologies (Bell \& Lightner 1988 p. 114, Lightner 1996 p. 304).

Detection of viruses by polymerase chain reaction (PCR). DNA was isolated from the gill and hepatopancreas tissues of 15 shrimp and 90 palaemonid prawns (30 per season) using a Wizard Genomic DNA kit (Promega). DNA was amplified using IQ2000 PCR kits (GeneReach) for detection of WSSV and IHHNV using the protocols specified by the manufacturer. Negative and positive controls were used in each test.

Infection parameters. The prevalence and severity of infection were quantified according to Bush et al. (1997). The criteria for pathology, proposed by Lightner (1996 p. 304) and Chávez-Sánchez et al. (2002), were based on an ascending scale of severity ranging from 1 to 4 .

Statistical analysis. Significant differences in the seasonal prevalence of parasites were identified using a $\chi^{2}$ analysis. Seasonal differences in the abundance of parasites were identified with a 1-way analysis of variance (ANOVA; $95 \%$ confidence level) after $\log (x+1)$ transformation of the data (STATISTICA V 7.0 software).

\section{RESULTS}

\section{Biometrics}

Geometric means of shrimp TL and weight were $10.1 \pm 2.1 \mathrm{~cm}$ and $7.4 \pm 5.6 \mathrm{~g}$, respectively. Of the 
shrimp caught, $43 \%$ were juveniles for which gender was difficult to determine. Of the sub-adults, $37 \%$ were male and $20 \%$ were female. The geometric means of the palaemonid prawn TL and weight were $6.6 \pm 1.4 \mathrm{~cm}$ and $5.6 \pm 4.0 \mathrm{~g}$, respectively. Juvenile prawns were trapped in each season (dry 60.5\%; northwind $78.3 \%$; rainy $53.3 \%$ ). No males were trapped in the dry season.

\section{Parasitology}

Gregarines of the genus Nematopsis were observed in the anterior and medial intestine of 15 (17\%) of the 91 shrimp examined, and cestodes of the genus Prochristianella were found within the hepatopancreas of $1 \%$ of the shrimp. Third-stage larvae of the nematode Physocephalus sexalatus (Fig. 1) were observed in the stomach of $3(3 \%)$ shrimp. The gills of $45(49 \%)$ shrimp harbored colonies of the Ascophrys sp. epibiont (Table 1). Larvae of an unidentified cestode were also observed in the intestine of 43 (47\%) shrimp; this cestode had the highest average intensity, and the highest degree of infection, while $P$. sexalatus had the lowest (average intensity of 1 , and 1 degree of infection).

Three protozoan epibionts were observed in palaemonid prawns. Epistylis sp. occurred on pleopods, periopods and uropods (Fig. 2A); Lagenophrys sp. occurred on gills and uropods (Fig. 2B); and Acineta sp. occurred mainly on periopods (Fig. 2C). An unidentified ciliate of the subclass Apostomatia was also observed in gill tissue (Fig. 3A), and a gregarine endoparasite - in both its schizont form (trophozoite with 2 divisions) (Fig. 4) and gametocyte form (not shown) - was observed in the anterior and medial intestine.

In prawns, the unidentified ciliate was highly prevalent (91 to $100 \%$ ) during all seasons, and Epistylis sp. (58 to $89 \%$ ) and gregarines (13 to $57 \%$ ) were common (Table 2). In addition, Lagenophrys sp. was prevalent (60 to $70 \%$ prawns) only in the dry and

Table 1. Infection by various parasites in wild white shrimp Litopenaeus setiferus $(\mathrm{n}=91)$. Degree of infection according to Lightner (1996 p. 304) and Chávez-Sánchez et al. (2002)

\begin{tabular}{|lccc|}
\hline Parasite & $\begin{array}{c}\text { Prevalence } \\
(\%)\end{array}$ & $\begin{array}{c}\text { Average } \\
\text { intensity } \\
( \pm \mathrm{SD})\end{array}$ & $\begin{array}{c}\text { Degree of } \\
\text { infection }\end{array}$ \\
\hline Nematopsis sp. & 17 & $16 \pm 8$ & 2 \\
Ascophrys sp. & 49 & $8 \pm 3$ & 2 \\
Unidentified cestode & 47 & $80 \pm 24$ & 4 \\
Prochristianella sp. & 1 & $5 \pm 0$ & 1 \\
Physocephalus sexalatus & 3 & $1 \pm 0$ & 1 \\
\hline
\end{tabular}

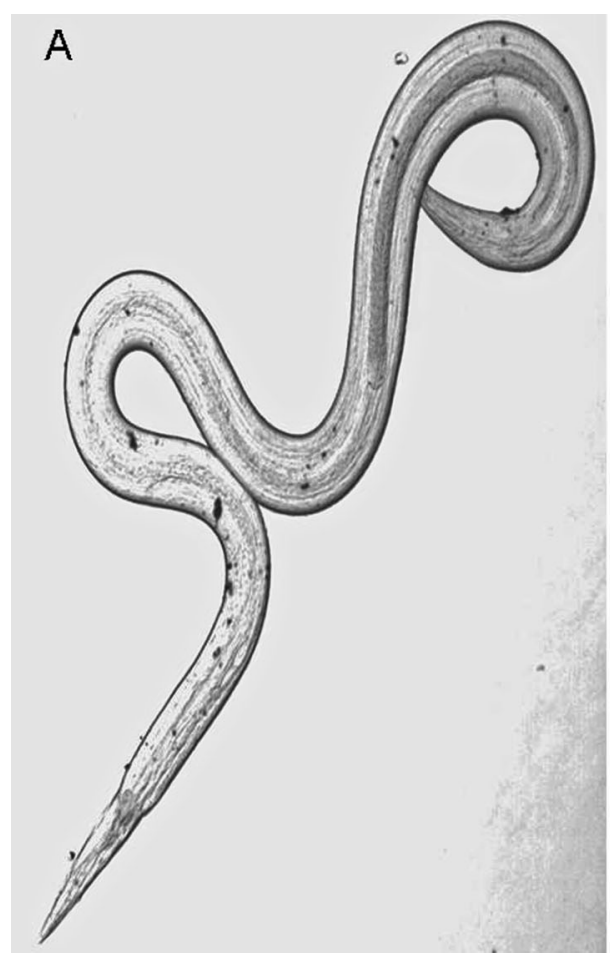

B

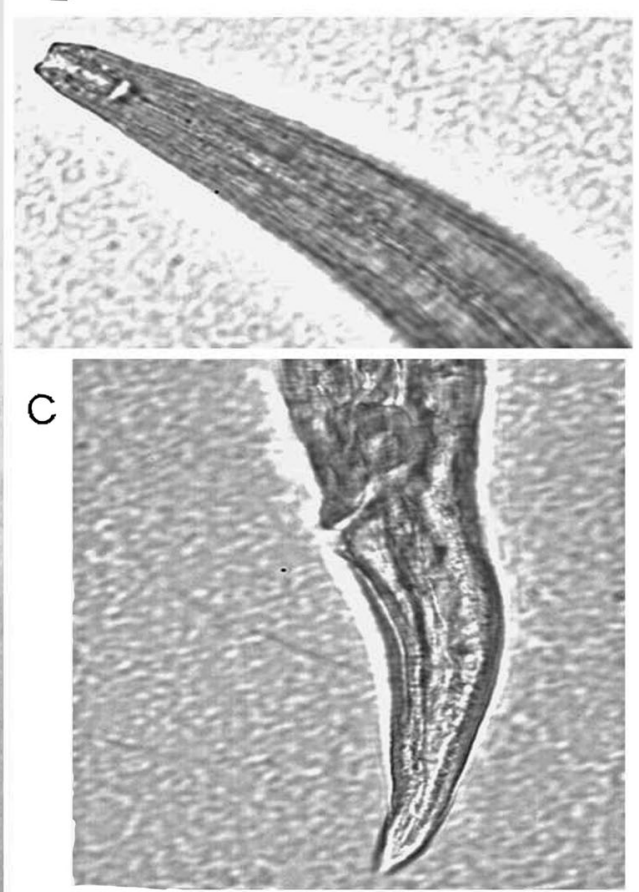

Fig. 1. (A) Third-stage larva of Physocephalus sexalatus from the stomach of the shrimp Litopenaeus setiferus (40x).

(B) Anterior and (C) posterior end of the larva 
rainy seasons, and Actineta sp. was observed only in some $(20 \%)$ prawns in the rainy season. Except for the unidentified ciliate $(p<0.05)$, no significant differences in prevalence of parasites occurred during each season. The average intensity was highest with Epistylis sp. (14.45) followed by the unidentified cili-
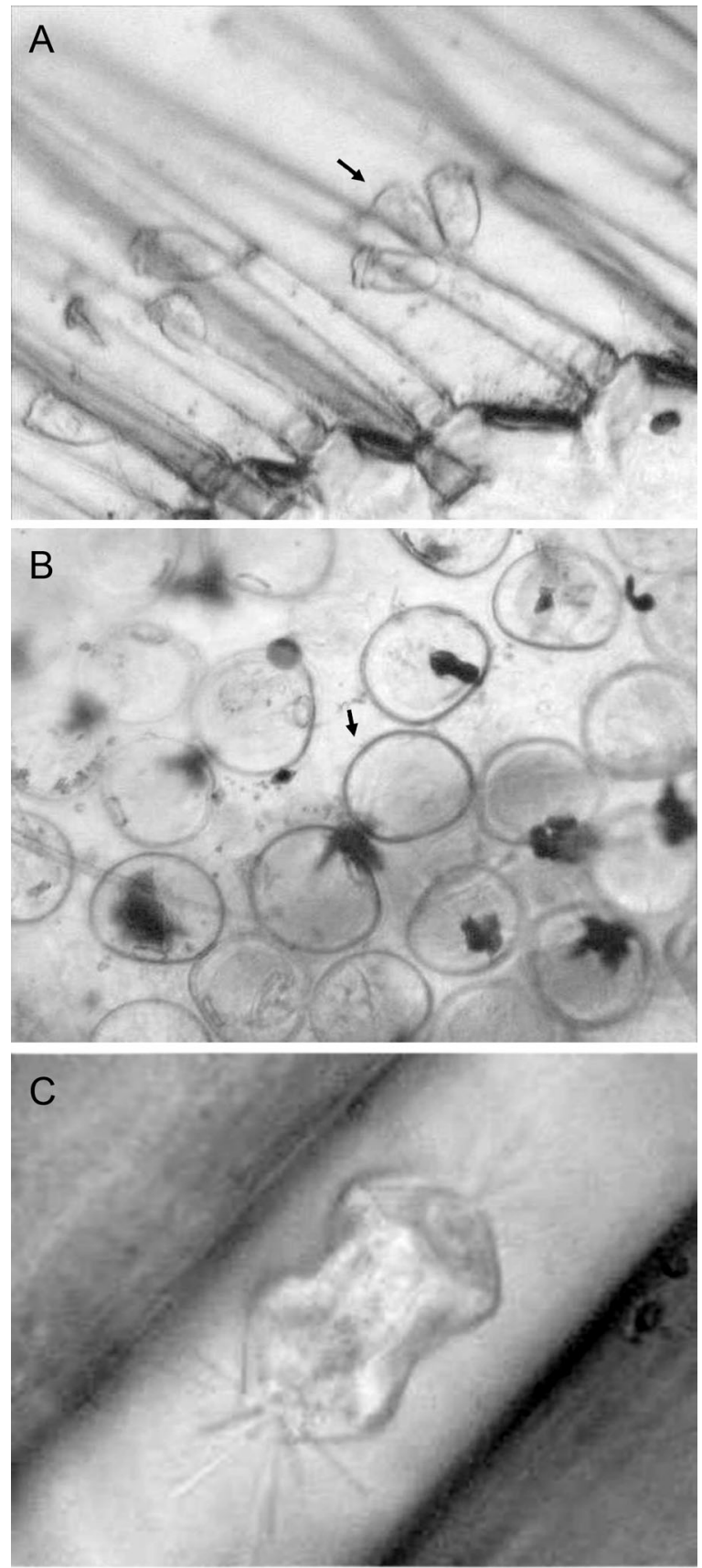

Fig. 2. Epibionts described from the palaemonid prawn Macrobrachium acanthurus. (A) Epistylis sp. observed on uropods (arrow). (B) Lagenophrys sp. from gills (arrow). (C) Dorsal view of Acineta sp. on the surface of periopods (40x)
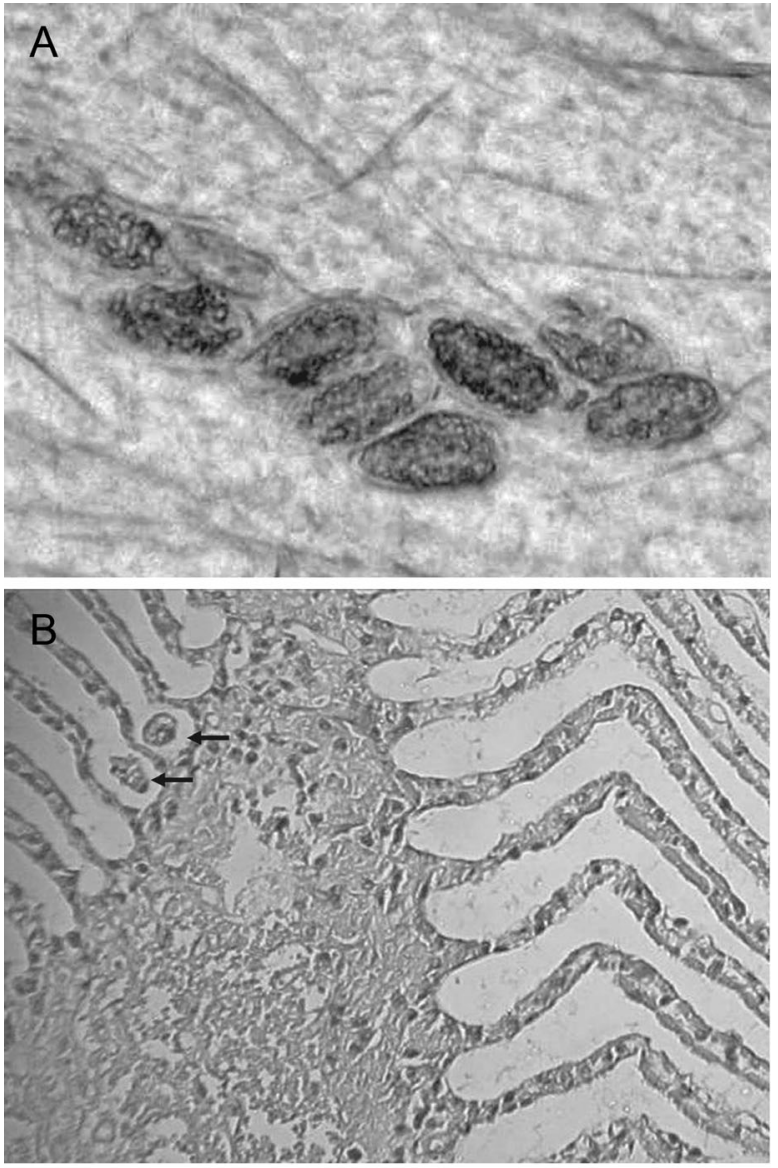

Fig. 3. (A) Unidentified ciliate of the subclass Apostomatia from gill tissue $(10 \times)$. (B) Histological section of gills; no apparent damage has been produced by the presence of the ciliate (arrows) $(10 \times)$

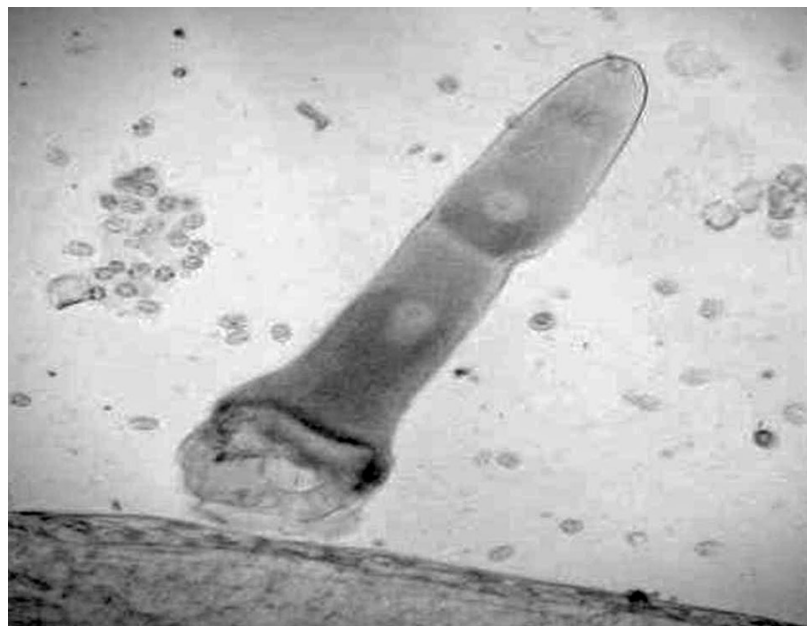

Fig. 4. Schizont form of the endoparasite gregarine Nematopsis sp. $(10 \times)$ 
Table 2. Infection by various parasites in the palaemonid prawn Macrobrachium acanthurus. Northwind, $\mathrm{n}=45$; Dry, $\mathrm{n}=38$; Rainy, $\mathrm{n}=30$

\begin{tabular}{|c|c|c|c|c|c|}
\hline Season & Epistylis & Lagenophrys & Acineta & Gregarine & Ciliate \\
\hline \multicolumn{6}{|c|}{ Prevalence $(\%)$} \\
\hline Northwind & 89 & 0 & 0 & 13 & 95 \\
\hline Dry & 58 & 60 & 0 & 58 & 91 \\
\hline Rainy & 80 & 70 & 20 & 57 & 100 \\
\hline$\chi^{2}$ statistic & $11.22^{\mathrm{a}}$ & $48.25^{\mathrm{a}}$ & $17.53^{\mathrm{a}}$ & $21.90^{\mathrm{a}}$ & $2.47^{\mathrm{b}, \mathrm{c}}$ \\
\hline \multicolumn{6}{|c|}{ Average intensity $( \pm \mathrm{SD})$} \\
\hline Northwind & $14.5 \pm 4.1$ & 0 & 0 & $2.7 \pm 1.0$ & $11.7 \pm 3.8$ \\
\hline Dry & $5.4 \pm 3.1$ & $9.2 \pm 2.9$ & 0 & $8.1 \pm 3.3$ & $9.3 \pm 3.5$ \\
\hline Rainy & $6.8 \pm 2.9$ & $12.6 \pm 7.2$ & $4.1 \pm 1.8$ & $8.1 \pm 2.6$ & $15.7 \pm 3.3$ \\
\hline \multicolumn{6}{|c|}{ Degree of infection } \\
\hline Northwind & 4 & 0 & 0 & 1 & 3 \\
\hline Dry & 2 & 3 & 0 & 1 & 3 \\
\hline Rainy & 3 & 4 & 1 & 1 & 3 \\
\hline \multicolumn{6}{|c|}{ 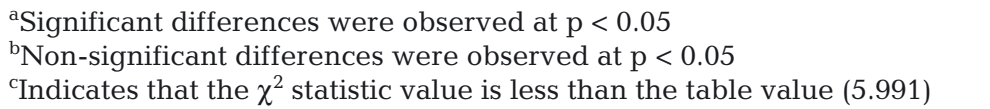 } \\
\hline
\end{tabular}

is a natural habitat for these species (Ismael \& New 2000). The 4 parasites (Ascophrys sp., Nematopsis sp., Prochristianella sp. larvae, and the unidentified cestode) detected in $L$. setiferus have been reported previously in wild and farmed penaeid shrimp as well as in other crustaceans from the Gulf of Mexico (Aldrich 1965, Lightner 1996 p. 304, Chávez-Sánchez et al. 2002, Vidal-Martínez et al. 2002, 2006, López-Téllez et al. 2009). However, the infection parameters that we observed showed some differences. For example, Prochristianella sp. was seen in only 1 of the 91 shrimp examined, compared to a prevalence of 33 to $94 \%$ reported previously (Aldrich 1965, Chávez-Sánchez et al. 2002, Vidal-Martínez et al. 2002). Ascophrys was also more prevalent in the $L$.

ate (11.7) during the northwind season. Gregarines showed the maximum degrees of infection during the dry (8.09) and rainy (8.05) seasons. Overall, Macrobrachium acanthurus showed the highest prevalence of parasites during the rainy season (Table 2).

\section{Histology}

A low-grade inflammatory reaction in the epithelium was observed near the location of the unidentified cestode. Colonies of the epibiont Ascophrys sp. in gills were associated with signs of cellular necrosis and tissue melanization, as were the colonies of Ascophrys sp. ciliates. Among the palaemonid prawns examined, only a single ciliate was found in gill lamellae, with apparently no histological damage in the adjacent tissue (Fig. 3B).

\section{PCR for WSSV and IHHNV}

All shrimp and palaemonid prawns analysed were PCR-negative for WSSV and IHHNV.

\section{DISCUSSION}

The presence of juvenile and adult individuals of the palaemonid prawn Macrobrachium acanthurus and the shrimp Litopenaeus setiferus in the study area of the Jamapa River region in Mexico confirmed that this setiferus that we examined (49\%) compared with the figure reported previously (3\%) (Chávez-Sánchez et al. 2002). These differences could be due to many factors, including sample size and environmental conditions at sampling locations near the mouth of the Jamapa River; for instance, shrimp at these sampling locations had most likely migrated recently from wetland brackish water (18 ppt) to more saline water environments (Jiménez-Badillo 2006).

As wild and domestic mammals of the family Suidae are primary hosts of Physocephalus sexalatus (Molin 1860), it was of some interest that third-stage nematode larvae were detected in a few (3\%) of the shrimp Litopenaeus setiferus. Adult stages can occur in tapirs, chickens, armadillos, horses, cows and lagomorphs (Goldberg et al. 1994, Nganga et al. 2008), and third-stage larvae can occur in fish which act as a paratenic host (Moravec et al. 1995). However, due to its low prevalence $(3 \%)$ and low infection score (2), whether $L$. setiferus shrimp can be a paratenic host for $P$. sexalatus, or whether the detection of this nematode followed a purely accidental transmission caused by nearby human activities, remains to be determined.

About $80 \%$ of shrimp Litopenaeus setiferus that we examined exhibited low-grade cell necrosis and tissue melanization in gills similar to that reported by Chávez-Sánchez et al. (2002), who attributed such histolopathology to the ciliate Ascophrys. Although the degree of infection was low (score $=1$ ), this could be sufficient for $L$. setiferus to mount a defence response to the chitinase produced by ciliates of the subclass Apostomatia - an enzyme which erodes the 
host cuticle (Bradbury \& Goyal 1976) and stimulates hemocytic infiltration and inflammation at the site of attachment as well as in the surrounding tissue (Couch 1983, Edgerton et al. 2002).

The unidentified cestode larvae observed in the intestine of the wild Litopenaeus setiferus have been reported previously in this species as well as in wild Farfantepenaeus aztecus (Chávez-Sánchez et al. 2002). A high abundance of this cestode could compromise nutrient absorption, leading to nutritional deficiencies and reduced growth rates.

Gregarines of the genus Nematopsis have been detected in the anterior and medial intestine of shrimp, in particular Cephalolobus penaeus, while Nematopsis penaeus has been associated with histopathology in the intestinal epithelium and hepatopancreas of wild Litopenaeus setiferus, Farfantepenaeus aztecus and $F$. duorarum, and cultured $L$. vannamei (Jiménez et al. 2002, Vidal-Martínez et al. $2002,2006)$. These organisms damage the intestinal epithelium, interfering with nutrient absorption and thus growth. In cultured juvenile shrimp, severe infections by gregarines can cause physical damage, including abnormal yellow pigmentation along the exoskeleton that can compromise product quality and value (Lightner 1996 p. 304).

The very low prevalence $(<1 \%)$ of Prochristianella sp. we found in Litopenaeus setiferus contrasts with that (90 to $100 \%$ ) detected in previous studies of L. setiferus in Mexico (Chávez-Sánchez et al. 2002, Vidal-Martínez et al. 2002, 2006 \& López-Téllez et al. 2009). This might be due to the collection of L. setiferus from brackish water rather than from more saline environments (Lightner 1996 p. 304). The constant presence of epibionts (mainly Epistylis sp.), and the ciliate, in shrimp during all 3 seasons was probably promoted by the high levels of organic matter in the area. While no evidence of damage to the hepatopancreas was observed in association with the larvae of Prochristianella sp., a higher severity of infection in wild $L$. setiferus and Farfantepenaeus aztecus is known to cause severe damage (Chávez-Sánchez et al. 2002).

The presence of epibionts in the specimens of palaemonid prawn Macrobrachium acanthurus that we examined is consistent with aquatic environments containing high loads of organic matter (Johnson \& Bueno 2000). In larval M. rosenbergii, abundant colonization of the exoskeleton by Acineta sp. and Epistylis sp. can hinder moulting and growth, causing death in cases of extreme parasitosis (Jayasree et al. 2001). In contrast, Epistylis sp. can occur on the periopods, uropods and eggs of cultured $M$. rosenbergii and $M$. tenellum without substantially affecting health. Epibionts of Acineta sp., Epistylis sp., Lagenophrys sp. and Ascophrys sp. are known to infect penaeid shrimp and palaemonid prawns, but they also occur in other crustaceans, such as crabs Portunus pelagicus and Callinectes sapidus (Shields 1992, Ma \& Overstreet 2006) and crayfish Pacifastacus leniusculus, Cherax quadricarinatus, Austropotamobius pallipes, Astacus astacus, Procambarus clarkii, Procambarus zonanguls (Edgerton et al. 2002), and thus appear to have no strong host preference.

The finding of gregarines on Macrobrachium acanthurus indicates for the first time that, in addition to marine species, infestations can occur in brackish water species. While juvenile and adult stages of this species generally inhabit freshwater environments, it migrates to brackish waters to reproduce, which is where the infestation was probably acquired (Ismael \& New 2000).

The absence of PCR-detectable WSSV and IHHNV in either wild shrimp Litopenaeus setiferus or prawn Macrobrachium acanthurus suggests that either the Jamapa River region is free of these viruses or that the prevalence of infection is extremely low, probably because shrimp farming is only now beginning to develop in Veracruz state. This finding is important as both viruses occur in wild and cultured penaeid shrimp elsewhere throughout the Americas; thus, WSSV often causes massive losses in farmed shrimp, especially in Ecuador (Lightner \& Redman 1998), and IHHNV seriously affects $L$. stylirostris fisheries in the northern Gulf of California, Mexico (Pantoja et al. 1999).

As our samples of wild shrimp Litopenaeus setiferus and prawn Macrobrachium acanthurus harbored potentially damaging parasites, including protozoans and helminths, there are risks that these parasites may be translocated if shrimp and/or prawns are collected for use in aquaculture. Although health risks posed by cestodes and helminths are low, due to the complexity of their life cycles, some value might be derived from monitoring for various parasites in cultured and wild crustacean populations along the coast of the Gulf of Mexico as a component of disease-prevention programs. Serious disease caused by these agents could diminish natural crustacean populations, negatively affecting catch volumes and causing economic repercussions to fisheries in the region (Jiménez-Badillo 2006).

Acknowledgements. Special thanks are given to the Mexican Science and Technology Council (CONACYT) for a postgraduate scholarship to M.E.D.M. (Grant 201416). The authors thank G. Cisneros-Hernández, J. Perez-Vega and 
Y. Zapata-Varela, Immunology and Molecular Biology Laboratory, CINVESTAV-Unidad Mérida, for assistance with PCR, and Dr. H. H. Mejía-Madrid, Aquatic Pathology Laboratory, CINVESTAV-Unidad Mérida, for assistance in identifying larvae of the nematode Physocephalus sexalatus. A specimen of $P$. sexalatus was deposited in the Helminthological Collection at CINVESTAV-Merida (Cat. No. 522).

\section{LITERATURE CITED}

Aguirre-Guzmán G, Ascencio-Valle F (2000) Infectious disease in shrimp species with aquaculture potential. Recent Res Dev Microbiol 4:333-348

- Aldrich DV (1965) Observation on the ecology and life cycle of Prochristianella penaei Kruse (Cestoda: Trypanorhyncha). J Parasitol 51:370-376

Bell TA, Lightner DV (1988) A handbook of normal paneid shrimp histology. World Aquaculture Society, Baton Rouge, LA

Bradbury PC, Goyal V (1976) The fine structure of a parasitic ciliate, Terebrospira, during ingestion of the exoskeleton of a shrimp, Palaemonetes. Tissue Cell 8:573-582

Bush AO, Lafferty KD, Lotz JM, Shostak AW (1997) Parasitology meets ecology on its own terms: Margolis et al. revisited. J Parasitol 83:575-583.

Chávez-Sánchez MC, Hernández-Martínez M, Abad-Rosales S, Fajer-Ávila E, Montoya-Rodríguez L, ÁlvarezTorres P (2002) A survey of infectious diseases and parasites of penaeid shrimp from the Gulf of Mexico. J World Aquacult Soc 33:316-329

Couch JA (1983) Diseases caused by protozoa. In: Provenzano AJ (ed) The biology of Crustacea, Vol 6. Pathobiology. Academic Press, London, p 79-107

Edgerton BF, Evans LH, Stephens FJ, Overstreet RM (2002) Synopsis of freshwater crayfish diseases and commensal organisms. Aquaculture 206:57-135

> Fernández-Leborans G, Zitzler K, Gabilondo R (2006) Protozoan ciliate epibionts on the freshwater shrimp Caridina (Crustacea, Decapoda, Atydae) from the Malili lake system on Sulawesi (Indonesia). J Nat Hist 40:1983-2000

Goldberg SR, Bursey CR, Holshuh HJ (1994) Physocephalus sp. (Spurida, Spirocercidae) larvae in stomach granulomas of the blue spiny lizard Sceloporus serrifer (Phrynosomatidae) from Texas. J Wildl Dis 30:274-276

Gracia A, Hernández-Aguilera JL 2005. Camarones peneidos. In: Hernández JL, Ruiz JA, Toral-Almazán RE, Arenas V (eds) Camarones, langostas y cangrejos de la costa este de México. CONABIO, Mexico DF, p 23-47

Ismael D, New B (2000) Biology. In: New B, Valenti WC (eds) Freshwater prawn culture. The farming of Macrobrachium rosenbergii. Blackwell Science, Oxford, p 18-22

> Jayasree L, Janakiram P, Madhavi R (2001) Epibionts and parasites of Macrobrachum rosenbergii and Metapenaeus dobsoni from Gosthani estuary. J Nat Hist 35:157-167

Jiménez R, de Barniol L, Machuca M (2002) Nematopsis marinus: a new septate gregarine from cultured penaeid shrimp Litopenaeus vannamei (Boone) in Ecuador. Aquacult Res 33:231-240

Jiménez-Badillo ML (2006) Caracterización de la pesca en la zona costera veracruzana. In: Moreno-Casasola P, Peres-

Editorial responsibility: Jeff Cowley,

Brisbane, Queensland, Australia barbosa Rojas E, Travieso Bello AC (eds) Estrategias de manejo costero integral: el enfoque municipal. Instituto de Ecología y Comisión Nacional de Áreas Naturales Protegidas Xalapa, VER, Sección II, p 273-280

Johnson SK, Bueno S (2000) Health management. In: New B, Valenti WC (eds) Freshwater prawn culture: the farming of Macrobrachium rosenbergii. Blackwell Science, Oxford, p 241

Lightner DV (1996) Handbook of shrimp pathology and diagnostic procedures for diseases of cultured penaeid shrimp. World Aquaculture Society, Baton Rouge, LA

> Lightner DV, Redman RM (1998) Strategies for the control of viral diseases of shrimp in the Americas. Fish Pathol 33: $165-180$

> López-Téllez N, Vidal-Martínez VM, Overstreet RM (2009) Seasonal variation of ectosymbiotic ciliates on farmed and wild shrimps from coastal Yucatán, Mexico. Aquaculture 287:271-277

Lorán-Nuñez RM, Martínez-Isunza FR (2002) Pesquería de langostino. In: Guzmán Amaya P, Quiroga Brahms C, Díaz Luna C, Fuentes Castellanos D, Contreras C, SilvaLópez G (eds) La Pesca en Veracruz and sus perspectivas de desarrollo. SAGARPA. Instituto Nacional de Pesca. Universidad Veracruzana, Veracruz, p 212-215

Ma H, Overstreet RM (2006) Two new species of Epistylis (Ciliophora: Peritrichida) on the blue crab Callinectes sapidus in the Gulf of Mexico. J Eukaryot Microbiol 53: 85-95

Moravec F, Vivas-Rodríguez C, Scholz T, Vargas-Vázquez J, Mendoza-Franco E, Schmitter-Soto JJ, González-Solís D (1995) Nematodes parasitic in fishes of cenotes (= sinkholes) of the Peninsula of Yucatán. Mexico, Part 2. Larvae. Folia Parasitol (Praha) 42:199-210

Nganga CJ, Naranja DN, Mutune MN (2008) The prevalence of gastrointestinal helminth infections in pigs in Kenya. Trop Anim Health Prod 40:331-334

> Pantoja CR, Lightner D, Holtshmit KH (1999) Prevalence and geographic distribution of infectious hypodermal and hematopoietic necrosis virus (IHHHNV) in wild blue shrimp Penaeus stylirostris from the Gulf of California, Mexico. J Aquat Anim Health 11:23-34

Schultz RL, Villegas JR, Severino-Hernández CA (2002) Pesquerías de Camarón. In: Guzmán Amaya P, Quiroga Brahms C, Díaz Luna C, Fuentes Castellanos D, Contreras C, Silva-López G (eds) La Pesca en Veracruz and sus perspectivas de desarrollo. SAGARPA. Instituto Nacional de Pesca. Universidad Veracruzana, Veracruz, p 195-201

Shields JD (1992) Parasites and symbionts of the crab Portunus pelagicus from Moreton Bay, eastern Australia. J Crustac Biol 12:94-100

Vidal-Martínez VM, Jiménez-Cueto AM, Simá-Álvarez R (2002) Parasites and symbionts of native and cultured shrimps from Yucatán, México. J Aquat Anim Health 14: $57-64$

Vidal-Martínez VM, Aguirre-Macedo ML, Del RíoRodríguez R, Gold-Bouchot G, Rendón-Von O, MirandaRosas GA (2006) The pink shrimp Farfantepenaeus duorarum, its symbionts and helminths as bioindicators of cheminal pollution in Campeche Sound, México. J Helminthol 80:159-174

Submitted: October 4, 2010; Accepted: June 30, 2011

Proofs received from author(s): August 31, 2011 